\title{
The Link Between Green Human Resource Management and Green Management Practices in Achieving Green Competitive Advantage: The Moderating Role of Stakeholder Pressure
}

Bazliani Muntari, Theresa C. F. Ho, Poh-Chuin Teo, Adriana Mohd Rizal, Ong Choon Hee

To Link this Article: http://dx.doi.org/10.6007/IJARBSS/v11-i8/10836 DOI:10.6007/IJARBSS/v11-i8/10836

Received: 10 June 2021, Revised: 15 June 2021, Accepted: 05 July 2021

Published Online: 22 August 2021

In-Text Citation: (Muntari et al., 2021)

To Cite this Article: Muntari, B., Ho, T. C. F., Teo, P.-C., Rizal, A. M., \& Hee, O. C. (2021). The Link Between Green Human Resource Management and Green Management Practices in Achieving Green Competitive Advantage: The Moderating role of Stakeholder Pressure. International Journal of Academic Research in Business and Social Sciences, 11(8), 1392-1401.

\section{Copyright: @ 2021 The Author(s)}

Published by Human Resource Management Academic Research Society (www.hrmars.com)

This article is published under the Creative Commons Attribution (CC BY 4.0) license. Anyone may reproduce, distribute, translate and create derivative works of this article (for both commercial and non-commercial purposes), subject to full attribution to the original publication and authors. The full terms of this license may be seen at: http://creativecommons.org/licences/by/4.0/legalcode

Vol. 11, No. 8, 2021, Pg. 1392 - 1401

Full Terms \& Conditions of access and use can be found at http://hrmars.com/index.php/pages/detail/publication-ethics 


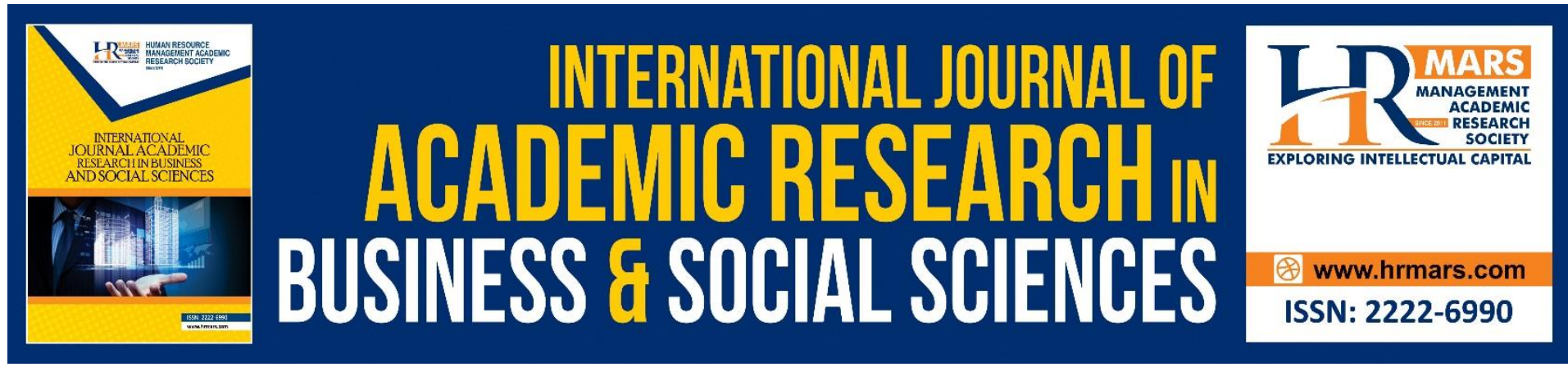

\title{
The Link Between Green Human Resource Management and Green Management Practices in Achieving Green Competitive Advantage: The Moderating Role of Stakeholder Pressure
}

\author{
Bazliani Muntari, Theresa C. F. Ho, Poh-Chuin Teo, Adriana \\ Mohd Rizal, Ong Choon Hee \\ Azman Hashim International Business School, Universiti Teknologi Malaysia, Malaysia
}

\begin{abstract}
Green Human Resource Management (GHRM) is important in ensuring that an organization's green initiatives and efforts are embraced by all their employees. Concerns on global warming, environmental issues, and also sustainability have come into serious agenda where most of the firms and organizations have actively taken action to expand and evolve in managing relationships with the natural environment by doing green management. Adopting major (GHRM) practices would lead to the implementation of Green Management practices (GMGT) in achieving Green Competitive Advantage (GCA). The aim of this paper is to develop a conceptual framework in establishing a link between GHRM, GMGT, and GCA. In addition, the role of stakeholder pressure as a moderator was also being examined in this study. This research is primarily a conceptual paper that draws on a database of past research and literature review in the area of GHRM. In addition, this research also proposed future studies to empirically examine the proposed relationship discussed in this paper.
\end{abstract}

Keywords: Green Human Resource Management, Green Management Practices, Green Competitive Advantage, Stakeholder Pressure.

\section{Introduction}

Concerns on global warming, environmental issues and sustainability is an important agenda. Environmental issues these days mostly come from green-house effect on the atmosphere and business operations cannot be separated from environmental deterioration especially in this industrial revolution era (Loknath \& Azeem, 2017). For example, in operation of the organization especially for manufacturing production where the use of waste products that have been dumped freely on the landfill which will cause problems to the environment in the long-run (Yacob, 2019). Many organizations anticipated that environmental issues, especially climate change where their company operates, would have a negative impact on their businesses in the long run. Pressure from the negative impact arising from environmental issues encourages organizations to be more responsible for the sustainable outcome specifically that can be related to the effects on the environment by their activities generally 
(Pham et al., 2019). More and more organizations are now aware of the importance of going green by integrating green practices in their management functions (Li et al., 2019). Hence, organizations are now slowly moving towards the going green although it is a challenging process (Yacob, 2019).

The practices towards sustainability have become crucial for the organizations for implementation as to control and reduce environmental impact (Cronstam et al., 2017) as such behaviour will help them to build a positive image which leads to increase in market share and profits (Yu \& Huo, 2019). However, tackling environmental issues is never an easy task for organizations yet there is one wisdom saying that "saving the environment, may hurt the businesses" by Walley and Bradley (1994) as there is still a perception that makes organizations afraid to make an environmentally move (Clarke et al., 2020). However, through implementation of sustainable green business practices is important for organizations to future-proof their brand, business viability and culture (Melbourne University, 2020) and should not be taken lightly.

There was a saying that businesses will always come together with the natural environment whether it will give impact or depend on it. However, a holistic management which include all the variables in organization and added Green concept has very broad as any effort to go green can be put under that term, for example green building, green development, green management or environmental management, green marketing that support to pursue and practice which environmental and ecologically friendly in lifestyle and design that can help for sustainability and energy efficient for future generations (Library, 2019). Therefore, the paper will focus on the Green Human Resource Management (GHRM) and Green Management (GMGT).

This conceptual paper endeavours to examine the impact of GHRM on GMGT and how it will pose an effect on the organization's Green Competitive Advantage (GCA). In addition, this paper also aims to examine the role of stakeholder pressure as a moderator that will strengthen the relationship between GHRM and GMGT.

The remainder of this paper is organised as follows. First this paper will review the relevant literature, build proposition and framework. Next, this paper will proceed to describe the research methodology to carry out the study followed by discussion and conclusion.

\section{Literature Review}

Underpinning Theories

Resource Based View

Penrose (1959); Hodgson (1988); Wernerfelt (1984) suggested that a firm should be viewed as an organised combination of resources and each organization is heterogeneous. Example of resources refers to tangible and intangible assets, capabilities and processes that the organisation possesses to create value. RBV was developed to serve as a tool to analyse and explain why some firms are able to achieve sustainable competitive advantage which leads firms to obtain above average returns (Grant, 1996). A firm should have a bundle of resources which are valuable, rare, hard to imitate for an organisation to achieve competitive advantage (Barney, 1991). In this research framework as depicted in Figure 1, GHRM and GMGT are the unique resources that a firm possesses which in turn will lead to GCA.

\section{Stakeholder Theory}

Stakeholders can be defined as individuals or groups of people who can influence and be influenced by an organization in achieving their organizational goals (Freeman and Reed, 
1983). These individuals and groups can be customers, community, shareholders, employees and government that may exert pressure on organizations to implement or not to implement certain strategies or actions in their business operations. The relationship and information gained from these stakeholders are valuable resources that can be utilized by the organization to gain competitive advantage (Freeman, Dmytriyev and Philips, 2021). In this research, stakeholder pressure plays a role as a moderator that will strengthen the relationship between GHRM and GMGT as depicted in Figure 1.

Research Variable

Green Human Resource Management (GHRM)

The studies on GHRM had been explored as to see the effects to the environmental practices performance although it will involve traditional practice of Human Resource Management (HRM) but it must be aligned with organization's goals and environmental strategic dimensions (Pham et al., 2019). GHRM can be defined as traditional HRM that is involved in environment management to ensure prevention of pollution in operational processes of organization (Renwick et al., 2013). There are a set of policies and practices that involve managing the workforce of organizations with bountiful knowledge towards eco-friendly and cost-efficient (Amrutha \& Geetha, 2020). Another study defined that GHRM is an action on the perspective of social sustainability where it focused on green employee acquisition, training, appraisal, rewards and involvement (Raut et al., 2019). The focused areas were divided into three which are developing green ability, motivating green employees and providing green opportunities (Pham et al., 2019).

\section{Green Management (GMGT)}

According to Haden et al. (2009) green management is defined as "organization-wide process of applying innovation to achieve sustainability, waste reduction, social responsibility, and a competitive advantage via continuous learning and development and by embracing environmental goals and strategies that are fully integrated with the goals and strategies of the organization" The aim of the management as to change, improve and revise the way how the organization operates as to ensure they follow the rules and regulations of environment which will improve economic, social and environment (Tam \& Taruna, 2016). This is to ensure a promising future for sustainability and long-lasting future. In protecting the environment, the organization will make a strategy to achieve their target and goal for green and sustainability with visible results for financial and the impact to the environment (Cronstam et al., 2017).

Other than that, environment and nature surrounding green where green management is very essential to give concern to environmental problems which need to be improved by managing and operating the businesses (Tam \& Taruna, 2016). On the other hand, green management also can be interpreted as any effort for "greening" with the purpose to concern on environmental safeguarding for future generation and welfare also included for cost cutting and inclining of profit (Taib \& Udin, 2015).

\section{Green Competitive Advantage (GCA)}

GCA refers to the situation where organizations gain a favourable competitive position utilizing green attributes or strategies where competitors are unable to imitate the successful environmental attributes or strategy, thus resulting in superior returns (Chen \& Chang, 2013). There is a growing awareness on the impact of global warming and pollution of the industrial 
waste on the future generation and businesses realized they can no longer afford to ignore the importance of going green (Goyal, 2016). In fact, according to a research done by Accenture (2019) which spans across North America, Europe and Asia reveals that consumers are willing to pay more for sustainable products. This shows that consumers are more concerned and receptive towards organizations and products that are environmentally responsible. Hence, by integrating green practices into the organization management and strategies can lead to higher profits and returns.

\section{Stakeholder Pressure}

The pressure from stakeholders such as the government, customers, and communities for more environmentally responsible organizations posed an impact on the likelihood in implementing green strategies (Kitsis and Chen 2021; Wolf 2014). Each stakeholders have their own demands on how organizations should behave such as consumers are pressuring for a more environmentally friendly product and processes, local communities demand for cleaner production processes while government advocate for compliance to environmental laws (Xiao et al., 2018) hence, the requirements and demands of the stakeholders to adopt certain green practices should not be taken lightly as stakeholders as each of the stakeholders are important for the continued existence of the organization (Baah et al., 2021).

\section{Research Proposition}

In this section, relationships between independent variables and dependent variables will be discussed to form a proposed research conceptual framework.

In GHRM, green aspects will be the biggest application in the functional activities of human resource where all the practices and policies are towards greening as to use scarce resources efficiently and environmentalism will be the source for morale and satisfaction of employees (Amrutha \& Geetha, 2020). According to Pham et al. (2019), GHRM practices include three factors that need to be developed in the organization which are: developing green ability whereas in selection and selection, training also job description; motivating green employees whereas performance management appraisal and reward system; providing green opportunities whereas organization learning, employee involvement and empowerment, supportive culture. From all the factors, it can be seen that developing green ability by training has given greater positive impact to green management in organization as it is important for entrusting the organization on the green system and process (Teixeira et al., 2012). Hence this study proposed that:

\section{Proposition 1: GHRM practices has a positive impact on implementation of GMGT}

GMGT is an organization-wide effort in finding ways in practicing and implementing ecofriendly processes and decisions for management (Haden, 2009). Organizations that manage to find ways of achieving sustainability through environmentally responsible products and processes can increase efficiency and improve corporate image (Sinjai et al. 2018) which can be used as a basis to gain green competitive advantage. Recent studies done by Hashim et.al, (2021) Sellitto et.al. (2020) and Sinjai et al., (2018) support the positive impact of GMGT on GCA. Based on the discussion above, this study proposed that:

Proposition 2: GMGT practices has a positive impact on GCA

Organization resources are focused on satisfying the most relevant stakeholders (Maso et. al. 2018), thus stakeholder pressure is proposed as a moderator that increases the strength of translating GHRM to GMGT practices. The pressure exerted by government, customers and 
communities will hasten the organizations effort to utilize their human resources in implementing their green initiatives strategies. For example, the pressure and demand from the government for a cleaner production with less pollution will drive organizations to utilize their resources (GHRM) in implementing the GMGT practices. The notion of stakeholder as moderator in corporate social responsibility was also supported by research done by Ye et al., (2021); Maso et al (2018): and Grewatsch \& Kleindienst (2017). Hence this study proposed that:

Proposition 3: Stakeholder pressure positively moderate the relationship between GHRM and GMGT.

Figure 1 depicts the proposed model and the relationships between the variables. In this study, the endogenous variable proposed is GCA. The exogenous variables in this model are GHRM and GMGT. Stakeholder Pressure is modelled as a moderator that is proposed to strengthen the relationship between GHRM and GMGT practices.

\section{Methodology}

Sample and Data Collection

The targeted population plan for this study would be Small and Medium Enterprises (SMEs) in Malaysia. Hence the unit of analysis is SMEs. The founder or manager who is actively managing the SMEs will be selected as respondents in this study. The inclusion criterion is the SMEs must have been operating for at least 3 years. Self- administered questionnaires will be the main method of data collection. Prior to receiving the questionnaire, participants will be given a cover letter explaining the purpose and to assure the respondents of their confidentiality.

Figure 1: Conceptual Framework

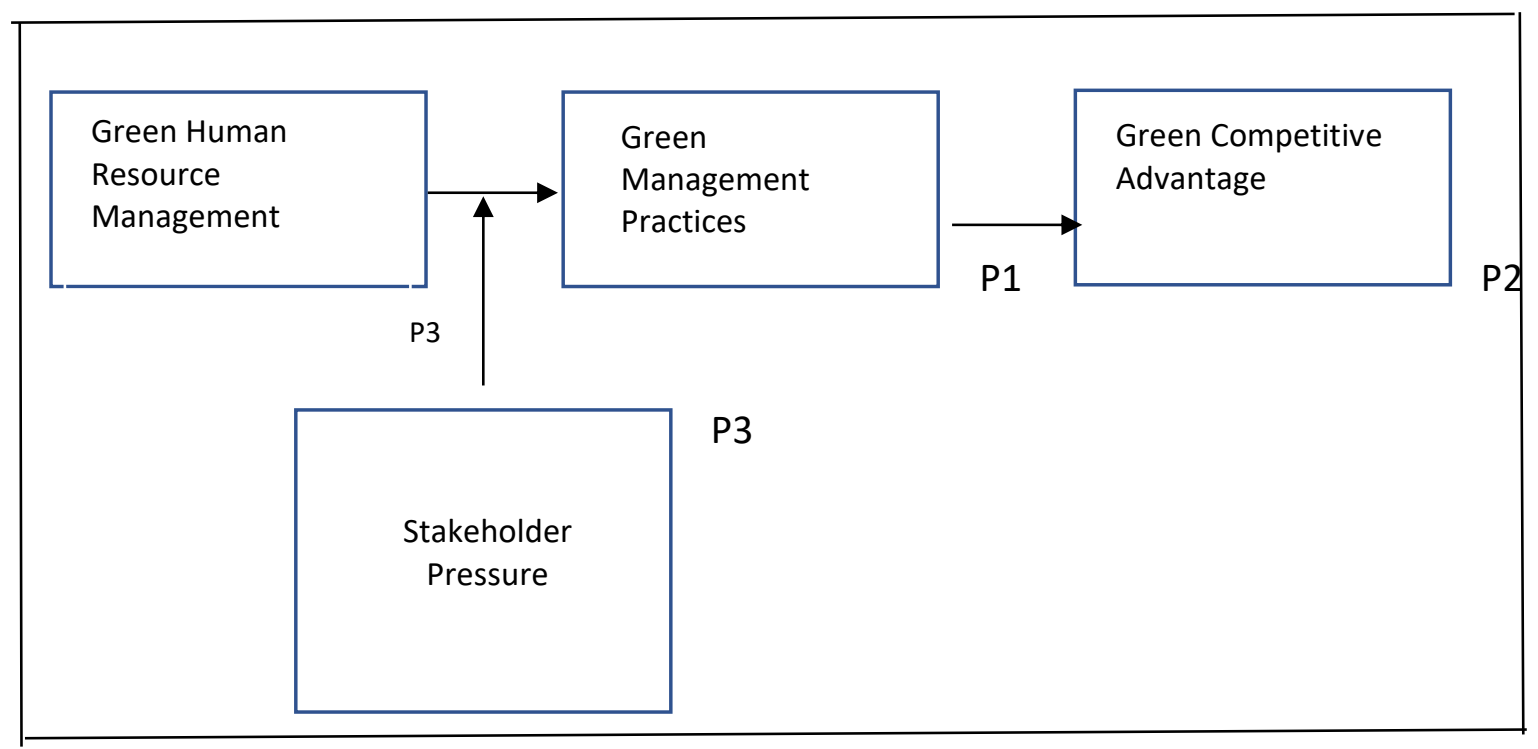

\section{Measures}

In assessing GHRM, this study will use the 22 items from the multidimensional GHRM questionnaire adopted from Nisar et al., (2021) and Mousa and Othman (2020) studies. This measurement consists of three dimensions that are: green hiring, green training and development, and the third dimension is green discipline management. As for GMGT the 
questions will be adapted from Roy and Khastagir (2016) which consist of 6 items. GCA were adopted from Lin and Chen (2017) and Chen and Chang (2013) which consist of 4 items. As for stakeholder pressure, 9 items were adopted from Kitsis and Chen (2021).

\section{Data Analysis}

This research will be using Statistical Package for Social Science (SPSS) and SmartPLS 3.2.8 (Ringle et al., 2015) to analyze the data gathered. Descriptive statistics such as mean, standard deviation and correlation coefficients will be analyzed using SPSS. This will be followed by the assessment of the measurement model by examining the validity and reliability of items via SmartPLS 3.2.8. Once the validity and reliability of the constructs are established, this study will examine the structural model of this study as shown in Figure 1.

\section{Discussion}

This paper provides an insight on the impact of GHRM on the GMGT practices which in turn will pose an impact on GCA in SMEs in Malaysia. Stakeholder pressure in this research was modelled as a moderator that will strengthen the relationship between GHRM Management and GMGT Practices. Organizations that have the right human resources, in the context of this study, employees who support and advocate the need for organizations to be environmentally responsible will have a high possibility in executing GMGT practices. As more and more customers start to place emphasis on going green, being an organization that is known for green practices would give a competitive edge over other competitors. The demand and requirement from the stakeholders would also expedite the translation of resources (human resources) into capabilities (GMGT).

\section{Limitation and Future Recommendation}

First, literature review of which this study proposition was based on a relatively small pool of literature which is limited in scope and breath. More study and research are needed in terms of depth before generalizing the result of this study. Secondly, this research has not been empirically tested yet. This research would suggest that future researchers examine empirically the relationship proposed in this framework.

\section{Conclusion}

In conclusion, in this conceptual paper, a review of management practices has been identified which are GHRM and GMGT practices that will lead to an organization in achieving GCA. This paper also posits the importance of the role of stakeholder in strengthening the relationship between GHRM and GMGT practices. Three research propositions have been developed to examine the relationships proposed in this research. More importantly, this paper provides an insight for scholarly research in the field of strategic management and corporate social responsibilities.

\section{References}

Accenture. (2019). Accenture Chemicals Global Consumer Sustainability Survey. Retrieved from: https://newsroom.accenture.com/news/more-than-half-of-consumers-wouldpay-more-for-sustainable-products-designed-to-be-reused-or-recycled-accenturesurvey-finds.htm

Al-Shboul, M. A., Garza-Reyes, J. A., \& Kumar, V. (2018). Best supply chain management practices and high-performance firms: The case of Gulf manufacturing firms. 
International Journal of Productivity and Performance Management, 67(9), 1482-1509. Amrutha, V. N., \& Geetha, S. N. (2020). A systematic review on green human resource management : Implications for social sustainability. Journal of Cleaner Production, 247, 119131. https://doi.org/10.1016/j.jclepro.2019.119131

Baah, C., Opoku-Agyeman, D., Acquah, I. S. K., Agyabeng-Mensah, Y., Afum, E., Faibil, D., \& Farid, A. M. A. (2021). Examining the correlations between stakeholder pressures, green production practices, firm reputation, environmental and financial performance: Evidence from manufacturing SMEs, Sustainable Production and Consumption, 27, 100114.

Barney, J. B. (1991). Firm resources and sustained competitive advantage. Journal of Management, 17(1), 99-120

Bon, A. T. (2018). Green human resource management, Green supply chain management practices and Sustainable performance. In Proceedings of the International Conference on Industrial Engineering and Operations Management (pp. 167-176).

Çankaya, S. Y., \& Sezen, B. (2019). Effects of green supply chain management practices on sustainability performance. Journal of Manufacturing Technology Management, 30(1), 98-121. https://doi.org/10.1108/JMTM-03-2018-0099

Chen, Y. S., Chang, C. H. (2013). The determinants of green product development performance: green dynamic capabilities, green transformational leadership, and green creativity. Journal of Business Ethics, 116(1), 107-119.

Clarke, R. A., Stavins, R. N., Greeno, J. L., Bavaria, J. L., Cairncross, F., Esty, D. C., ... Schot, J. (2020). The Challenge of Going Green.

Cronstam, O., Grönberg, J., \& Björling, M. W. (2017). Influencing Factors in the Implementation of Green Management Practices A Qualitative Study regarding Swedish SMEs in Logistics.

Freeman, R. E., Dmytrivev, S. D., \& Phillips, R. A. (2021). Stakeholder theory and the ResourceBased View of the firm. Journal of Management, 1-14. https://doiorg.ezproxy.utm.my/10.1177/0149206321993576

Freeman, R. E., \& Reed, D. L. (1983). Stockholders and stakeholders: A new perspective on corporate governance. California Management Review, 23(3), 88-106.

Goyal, N. G. (2021) Green products: How can they provide competitive advantage. Retrieved from: http://www.businessworld.in/article/Green-Products-How-Can-They-ProvideCompetitive-Advantage/24-03-2016-92234/

Grant, R. M. (1996). Prospering in dynamically competitive environments: Organizational capability as knowledge integration. Organization Science, 7(4), 375-387

Grewatsch, S., \& Kleindienst, I. (2017). When does it pay to be good? Moderators and mediators in the corporate sustainability-corporate financial performance relationship: A critical review. Journal of Business Ethics, 145, 383-416.

Hamidi, F., Chelliah, S., \& Halim, M. N. B. A. (2014). Green Management: Opportunities and Challenges in International Business for Malaysian SME. Journal of Asian Scientific Research, Asian Economic and Social Society, 4(1), 723-728.

Hashim Z., Wang, Y., Vasbieva, D. G., \& Abbas, Q. (2021). Exploring a pathway to carbon neutrality via reinforcing environmental performance through green process innovation, environmental orientation and green competitive advantage. Journal of Environmental Management, 296

Hodgson, G. M. (1998). Evolutionary and competence based theories of the firm. Journal of Economic Studies, 25(1), 25-56 
Kitsis, A. M., \& Chen, I. J. (2021). Do stakeholder pressures influence green supply chain Practices? Exploring the mediating role of top management commitment Journal of Cleaner Production, 316. https://doi.org/10.1016/j.jclepro.2021.128258.

Lee, K. (2009). Why and how to adopt green management into business organizations ? The case study of Korean SMEs in manufacturing industry. Management Decision, 47(7), 1101-1121. https://doi.org/10.1108/00251740910978322

Lee, S. (2015). The effects of green supply chain management on the supplier's performance through social capital accumulation. Supply Chain Management: An International Journal, 20(1), 42-55. https://doi.org/10.1108/SCM-01-2014-0009

Li, Y., Ye, F., Dai, J., Zhao, X., \& Sheu, C. (2019). The adoption of green practices by Chinese firms. International Journal of Operations \& Production Management, 39(18), 550-572. https://doi.org/10.1108/IJOPM-12-2017-0753

Library, M. T. (2019). Going Green - Sustainable Living Resource Guide.

Loknath, Y., \& Azeem, B. A. (2017). Green Management - Concept and Strategies. In National Conference on Marketing and Sustainable Development (pp. 688-702).

Maso, L. D., Mazzi, F., Soscia, M., \& Terzani, S. (2018). The moderating role of stakeholder management and societal characteristics in the relationship between corporate environmental and financial performance. Journal of Environmental Management, 218.

Melbourne University. (2020). Future proofing and the role of environmental sustainability in the workplace. Retrieved from: https://www.unimelb.edu.au/professionaldevelopment/insights/sustainability/future-proofing-sustainability

Micheli, G. J. L., Cagno, E., Mustillo, G., \& Trianni, A. (2020). Green supply chain management drivers, practices and performance: A comprehensive study on the moderators. Journal of Cleaner Production, 259. https://doi.org/10.1016/j.jclepro.2020.121024

Mousa, S. K., \& Othman, M. (2020). The impact of green human resource management practices on sustainable performance in healthcare organisations: A conceptual framework. Journal of Cleaner Production, 243. https://doi.org/10.1016/j.jclepro.2019.118595

Nisar, A. A., Haider, S., Ali, F., Jamshed, S., Ryu, K., \& Gill, S. S. (2021). Green human resource management practices and environmental performance in Malaysian green hotels: The role of green intellectual capital and pro-environmental behavior. Journal of Cleaner Production, 311. https://doi.org/10.1016/j.jclepro.2021.127504.

Penrose, E. T. (1959). The Theory of the Growth of the Firm. New York: John Wiley

Pham, N. T., Hoang, H. T., \& Phan, Q. P. T. (2019). Green human resource management : a comprehensive review and future research agenda. International Journal of Manpower, 1-34. https://doi.org/10.1108/IJM-07-2019-0350

Raut, R. D., Gardas, B., Luthra, S., Narkhede, B., \& Mangla, S. K. (2019). Analysing green human resource management indicators of automotive service sector. International Journal of Manpower, 1, 1-20. https://doi.org/10.1108/IJM-09-2019-0435

Renwick, D. W. S., Redman, T., \& Maguire, S. (2013). Green Human Resource Management : A Review and Research Agenda. International Journal of Management Reviews, 15(1), 1-14. https://doi.org/10.1111/j.1468-2370.2011.00328.x

Roy, M., \& Khastagir, D. (2016). Exploring role of green management in enhancing organizational efficiency in petro-chemical industry in India. Journal of Cleaner Production, 121, 109-115. https://doi.org/10.1016/j.jclepro.2016.02.039.

Shafique, M. N., Asghar, M. S., \& Rahman, H. (2017). The Impact of Green Supply Chain Management Practices on Performance : Moderating Role of Institutional Pressure with 
Mediating Effect of Green Innovation. Business, Management and Education, 15(1), 91108. https://doi.org/10.3846/bme.2017.354

Sellitto, M. A., Camfield, C. G., \& Buzuku, S. (2020). Green innovation and competitive advantages in a furniture industrial cluster: A survey and structural model. Sustainable Production and Consumption, 23.

Siebers, P.-O., Aickelin, U., Celia, H., \& Clegg, C. (2008). Multi-Agent Simulation and Management Practices. In Encyclopedia of Decision Making and Decision Support Technologies (p. 8).

Singjai, K., Winata, L., \& Kummer, T.F. (2018). Green initiatives and their competitive advantage for the hotel industry in developing countries. International Journal of Hospitality Management, 75, 131-143.

Taib, M. Y. M., \& Udin, Z. M. (2015). The development of green management and green technology in green manufacturing in malaysia mohd yazid md taib zulkifli mohamed udin. Journal of Technology and Operations Management, 10(1), 40-47.

Tam, H., \& Taruna. (2016). Green management : Road to sustainability \& corporate efficiency. International Journal of Applied Research, 2(1), 586-590.

Teixeira, A. A., Jabbour, C. J. C., \& Jabbour, A. B. L. de S. (2012). Relationship between green management and environmental training in companies located in Brazil : A theoretical framework and case studies. Int. J. Production Economics, 140, 318-329. https://doi.org/10.1016/j.ijpe.2012.01.009

Wernerfelt, B. (1984). A resource-based view of the firm. Strategic Management Journal, 5, 171-180

Wolf, J. (2014). The relationship between sustainable supply chain management, stakeholder pressure and corporate sustainability performance. Journal of Business Ethics 119, 317-328.

Xiao, C., Wang, Q., Donk, D. P., \& Vaart, T. (2018) When are stakeholder pressures effective? An extension of slack resources theory. International Journal of Production Economics, 199, 138-149.

Yacob, P. (2019). An empirical investigation of green initiatives and environmental sustainability for manufacturing SMEs. Journal of Manufacturing Technology Management, 30(1), 2-25. https://doi.org/10.1108/JMTM-08-2017-0153

Ye, M., Wang, H., \& Lu, W. (2021). Opening the "black box" between corporate social responsibility and financial performance: From a critical review on moderators and mediators to an integrated framework. Journal of Cleaner Production, 313.

Yu, W., Chavez, R., Feng, M., Yew, C., \& Fynes, B. (2019). Green human resource management and environmental cooperation: An ability-motivation-opportunity and contingency perspective. Intern. Journal of Production Economics, 219, 224-235. https://doi.org/10.1016/j.ijpe.2019.06.013

Yu, Y., \& Huo, B. (2019). The impact of environmental orientation on supplier green management and financial performance: The moderating role of relational capital. Journal of Cleaner Production, 211, 628-639. https://doi.org/10.1016/j.jclepro.2018.11.198

Zaid, A. A., Jaaron, A. A. M., \& Bon, A. T. (2018). The impact of green human resource management and green supply chain management practices on sustainable performance: An empirical study. Journal of Cleaner Production, 204 965-979. 